\title{
Effect of different glyphosate salts on phosphodiesterase and phosphotriesterase activities in soil with reference to ecological importance of soil pollution. A laboratory experiment
}

\author{
Odziaływanie różnych soli glifosatu na aktywność \\ fosfodiesterazy i fosfotriesterazy w glebie w odniesieniu \\ do ekologicznego znaczenia skażenia gleby. \\ Doświadczenie laboratoryjne
}

\footnotetext{
${ }^{*}$ Mgrinż. Maciej Płatkowski, dr hab. inż. Arkadiusz Telesiński, Department of Plant Physiology and Biochemistry, West Pomeranian University of Technology, Słowackiego 17 St., 71-434 Szczecin,
}

e-mail: maciej.platkowski@zut.edu.pl, arkadiusz.telesinski@zut.edu.pl,

Keywords: glyphosate, soil, phosphodiesterase, phosphotriesterase

Słowa kluczowe: glifosat, gleba, fosfodiesteraza, fosfotriesteraza

\begin{abstract}
The aim of this study is to determine the effect of the two glyphosate salts: isopropylamine and potassium (contained in preparations Roundup) on the activity of phosphodiesterase and phosphotriesterase in the soil. The experiment was carried out in the laboratory conditions on two soil types: loamy sand $\left(\mathrm{C}_{\text {org }} 8.70 \mathrm{~g} \cdot \mathrm{kg}^{-1}, \mathrm{pH}_{\mathrm{KCl}} 6.39\right)$ and sandy loam $\left(\mathrm{C}_{\text {org }} 10.90 \mathrm{~g} \cdot \mathrm{kg}^{-1}\right.$, $\mathrm{pH}_{\mathrm{KCl}} 6.81$ ). Two glyphosate salts (isopropylamine and potassium) in dosage of 0,1 and $100 \mathrm{mg} \cdot \mathrm{kg}^{-1}$ were applicate into soils. Phosphodiesterase and phospotriesterase activities in soils were determined spectrophotometrically on days $1,7,14,28$, 56 and 112. The obtained results were converted with respect to the enzyme activities in the control soil (assuming it to be $100 \%$ ) and given as percent of inhibition. The results were shown as environmental danger zones graphs. Obtained results showed that glyphosate salts application has primarily resulted in inhibition of phosphodiesterase activity, and stimulation of phosphotriesterase activity in soils. Soil type and kind of glyphosate salt affect the interaction of herbicide with phosphodiesterase and phosphotriesterase activities. The observed changes in the phosphodiesterase and phosphotriesterase activities caused by the addition of both glyphosate salts were located on environmental danger zones graphs in the range of negligible or acceptable values, which may indicate a low impact of herbicide on measured enzymes.
\end{abstract}

๑) IOŚ-PIB

\section{INTRODUCTION}

Phosphorus is one of the limiting nutrients for plant growth [Redel et al. 2007]. Organic phosphorus may constitute 20$80 \%$ of the total $\mathrm{P}$ in the surface soil [Turner and Haygarth

\section{Streszczenie}

Celem podjętych badań było określenie oddziaływania dwóch soli glifosatu: izopropyloaminowej oraz potasowej (zawartych w preparatach Roundup) na aktywność fosfodiesterazy i fosfotriesterazy w glebie. Doświadczenie przeprowadzono w warunkach laboratoryjnych na dwóch gatunkach gleb: piasku gliniastym $\left(\mathrm{C}_{\text {org }} 8,70 \mathrm{~g} \cdot \mathrm{kg}^{-1}, \mathrm{pH}_{\mathrm{KCl}} 6,39\right)$ i glinie lekkiej $\left(C_{\text {org }} 10,90 \mathrm{~g} \mathrm{~kg}^{-1}, \mathrm{pH}_{\mathrm{KCl}} 6,81\right)$. Do części ziemistych materiału glebowego wprowadzono sole glifosatu w ilościach 0,1 i $100 \mathrm{mg} \cdot \mathrm{kg}^{-1}$. W 1., 7., 14., 28., 56. i 112. dniu doświadczenia oznaczono spektrofotometrycznie aktywność fosfodiesterazy i fosfotriesterazy. Otrzymane wyniki przeliczono w stosunku do aktywności enzymów w glebie kontrolnej (przyjmując ją za $100 \%$ ) i podano jako procent inhibicji. Wyniki zmian aktywności badanych enzymów przedstawiono na wykresach ekologicznych stref zagrożenia. Dodatek do gleby glifosatu spowodował przede wszystkim inhibicję aktywności fosfodiesterazy oraz stymulację aktywności fosfotriesterazy w piasku gliniastym i glinie lekkiej. Gatunek gleby oraz rodzaj soli glifosatu wpływały na oddziaływanie herbicydu na aktywność fosfodiesterazy i fosfotriesterazy. Zaobserwowane zmiany aktywności fosfodiesterazy i fosfoteresterazy wywołane dodatkiem obu soli glifosatu znajdowały się na wykresach stref ekologicznego zagrożenia w obszarze wartości pomijalnych i tolerowanych, co może świadczyć o niewielkim wpływie herbicydu na oznaczane enzymy.

2005]. Among the organic $P$ form identified so far, inositol compounds, phospholipids and nucleic acids are dominant. Phosphorus is available to plants after it is hydrolysed into 
orthophosphate by phosphatases in the soils [Lemanowicz and Koper 2009]. Thus, the soil phosphatase activities greatly affect the bioavailability of organic $\mathrm{P}$. The phosphatases in soils include: phosphomonoesterases (for hydrolysing organic phosphate monoesters) and phosphodiesterase (for hydrolysing phosphate diesters), phosphotriesterases (for hydrolysing phosphate triesters) and also pyrophosphatase (which transfers pyrophosphate into orthophosphate) [Wang et al. 2011].

Phosphodiesterases and phosphotriesterases in soil are rather rarely studied compared to phosphomonoesterases. This seems a significant oversight, because phosphodiesterase and phosphotriesterase are involved in the degradation of phospholipids and nucleic acids, which constitute the majority of the fresh organic $P$ inputs to soil [Turner and Haygarth 2005]. According to Malghani et al. [2009], phosphodiesterases and phosphotriesterases also play an important role in the detoxification of organophosphate pesticide. Hydrolysis of the ester connection makes the compounds more vulnerable to further degradation [Kumar et al. 1996].

One of the most popular organophosphate pesticides is glyphosate ( $N$-phosphonomethylglycine). It is a broadspectrum, post emergence herbicide, which acts by binding phosphoenolpyruvate, the substrate of 5-enolpyruvylshikimate3-phosphate (EPSP) synthase, and subsequently, inhibiting aromatic amino acid synthesis via the shikimate pathway in plants [Forlani et al. 2008]. Without these amino acids, organisms are unable to synthesise certain proteins essential for metabolism [Lane et al. 2012]. Glyphosate is generally applied as part of a formulated product, the most widely used of which are the Roundup herbicides. Roundup formulations contain glyphosate in the form of an isopropylamine, potassium or ammonium salt, which aids solubility but does not affect its properties as the active ingredient [Webster et al. 2014].

Rating negative effects of pesticides or other xenobiotics on the environment is difficult, and to determine the severity and duration of adverse changes in the soil ecosystem may suffer from many problems [Wienhold et al. 2004]. Domsch et al. [1983] suggested the concept according to which all changes in the metabolism of the components of soil, caused by chemical agents, may be compared to changes caused by microorganisms under natural stress conditions. All changes of process lasting over 60 days with the severity of $50 \%$, compared to the control soil, are considered to be dangerous; others are regarded as acceptable or negligible.

The aim of this study is to determine the impact of glyphosate (contained in Roundup formulations in the form of isopropylamine or potassium salt) on phosphodiesterase and phosphotriesterase activities in soil with reference to ecological importance of soil pollution.

\section{MATERIALS AND METHODS}

Experiment was carried out on soil samples collected from arable and humus horizon: loamy sand and sandy loam. Characteristics of soils used in the research are presented in table 1.

Soil samples collected from the field were adjusted to air-dry state and sieved through a sieve with mesh of 2-mm diameter.
Table 1. Selected properties of soil used in the experiment

\begin{tabular}{|c|c|c|c|c|}
\hline $\begin{array}{c}\text { Granulometric } \\
\text { group }\end{array}$ & $\begin{array}{c}\mathbf{C}_{\text {org }} \text { content } \\
{\left[\mathbf{g} \cdot \mathbf{k g}^{-1}\right]}\end{array}$ & $\begin{array}{c}\mathbf{N}_{\text {total }} \text { content } \\
{\left[\mathbf{g} \cdot \mathbf{k g}^{-1}\right]}\end{array}$ & \multicolumn{2}{|c|}{$\mathbf{p H}$} \\
\hline Loamy sand & 8.70 & 0.71 & 6.56 & $1 \mathrm{M} \mathrm{KCl}$ \\
\hline Sandy loam & 10.90 & 1.39 & 7.09 & 6.81 \\
\hline
\end{tabular}

The soil material was divided into two series depending on the type of soil. In each series, glyphosate was introduced into $0.5 \mathrm{~kg}$ of soil. Samples were adjusted to $60 \%$ maximum water capacity. In the experiment, changeable factors were:

- kind of glyphosate salt: isopropylamine (contained in Roundup $360 \mathrm{SL}$ ) and potassium (contained in Roundup TransEnergy $450 \mathrm{SL}$ ),

- dosage of glyphosate: 0,1 , and $100 \mathrm{mg} \cdot \mathrm{kg}^{-1}$,

- day of experiment: $1,7,14,28,56,112$.

Soil samples were precisely stirred and stored in hermetic polyethylene bags at a temperature of $20^{\circ} \mathrm{C}$ and in a dark place. On days of measurements, enzyme activities were determined by spectrophotometry, using UV-1800 Shimadzu equipment: phosphodiesterase (EC 3.1.4.1), according to Browman and Tabatabai [1978] and phosphotriesterase (EC 3.1.8.1), according to Eivazi and Tabatabai [1977].

All analyses were done in three repetitions. A three-way analysis of variance (ANOVA) was used to examine the effect of glyphosate salts on soil phosphodiesterase and phosphotriesterase activities. To assess least significant differences (LSD), Tukey's test was used at a significant level $\alpha=0.05$. All statistics were done using Statistica 10.0 (StatSoft).

Real values of the enzyme activities were calculated in reference to activity in the control soil (assuming it as $100 \%$ ) and specified as percent of inhibition. Changes of phosphatases activity were shown as environmental danger zones graphs suggested by Domsch et al. [1983]. In the graphs, three ecological danger zones were marked: values negligible - with slight influence on enzymatic activity, values tolerable - with considerable influence on enzymatic activity but not cause inactivation of catalytic activity of enzymes, values critical - with the most negative impact on soil ecosystem that may cause degradation.

\section{RESULTS AND DISCUSSION}

In loamy sand, with both salts of glyphosate in dosage of $1 \mathrm{mg} \cdot \mathrm{kg}^{-1}$, significant inhibition of phosphodiesterase was shown on days 7, 14 and 56 (Table 2). Obtained enzyme activity decrease in case of isopropylamine salt was ranged from 7 to $13 \%$, and in case of potassium salt, from 13 to $15 \%$. Application of both glyphosate salts in amount of $100 \mathrm{mg} \cdot \mathrm{kg}^{-1}$ caused in all days decline of phosphodiesterase activity. Inhibition of this enzyme activity in loamy sand treated with isoporopylamine salt ranged from 20 to $40 \%$, and with potassium salt from 10 to $31 \%$. However, the level of inactivation of phosphodiesterse in the loamy sand with the addition of glyphosate, was in the range of negligible or acceptable values (Fig. 1). 
Table 2. Phosphodiesterase activity in soil treated with glyphosate salts [mg p-NP· $(\mathrm{kg} \mathrm{dm} \cdot \cdot \mathrm{h})^{-1}$ ]

\begin{tabular}{|c|c|c|c|c|c|c|c|c|}
\hline \multirow{2}{*}{$\begin{array}{l}\text { Glyphosate salt } \\
\text { (I) }\end{array}$} & \multirow{2}{*}{$\begin{array}{c}\text { Dose } \\
{\left[\mathbf{m g} \cdot \mathbf{k g}^{-1}\right] \text { (II) }}\end{array}$} & \multicolumn{7}{|c|}{ Day of experiment (III) } \\
\hline & & 1 & 7 & 14 & 28 & 56 & 112 & Mean \\
\hline \multicolumn{9}{|c|}{ Loamy sand } \\
\hline \multirow{4}{*}{ Isopropylamine } & 0 & 6.17 & 7.24 & 6.99 & 8.22 & 7.38 & 7.41 & 7.24 \\
\hline & 1 & 6.45 & 6.51 & 6.09 & 8.42 & 6.87 & 7.78 & 7.02 \\
\hline & 100 & 4.92 & 4.97 & 4.89 & 6.19 & 4.43 & 4.58 & 5.00 \\
\hline & Mean & 5.85 & 6.24 & 5.99 & 7.61 & 6.23 & 6.59 & 6.42 \\
\hline \multirow{4}{*}{ Potassium } & 0 & 6.17 & 7.24 & 6.99 & 8.22 & 7.38 & 7.41 & 7.24 \\
\hline & 1 & 6.22 & 6.30 & 5.97 & 8.41 & 6.36 & 7.48 & 6.79 \\
\hline & 100 & 4.67 & 5.01 & 5.23 & 7.41 & 5.33 & 5.43 & 5.51 \\
\hline & Mean & 5.69 & 6.18 & 6.06 & 8.01 & 6.36 & 6.68 & 6.51 \\
\hline \multicolumn{2}{|c|}{ Mean } & 5.77 & 6.21 & 6.03 & 7.81 & 6.29 & 6.68 & 6.47 \\
\hline $\mathrm{LSD}_{0.05}$ & \multicolumn{3}{|c|}{$\begin{array}{c}I=n s . \\
|x| \mid=0.217 \\
I x|I|=0.217\end{array}$} & \multicolumn{2}{|c|}{$\begin{array}{c}\|=0.184 \\
\|x\| I I=0.260 \\
I I x \| I I=0.450\end{array}$} & \multicolumn{3}{|c|}{$\begin{array}{c}\text { III }=0.318 \\
\text { III x I }=0.318 \\
\text { III x II }=0.551\end{array}$} \\
\hline \multicolumn{9}{|c|}{ Sandy loam } \\
\hline \multirow{4}{*}{ Isopropylamine } & 0 & 10.03 & 9.32 & 10.07 & 14.46 & 10.52 & 11.64 & 11.01 \\
\hline & 1 & 9.94 & 10.72 & 10.22 & 12.50 & 9.82 & 11.63 & 10.81 \\
\hline & 100 & 8.63 & 8.29 & 8.91 & 10.82 & 9.48 & 9.89 & 9.34 \\
\hline & Mean & 9.53 & 9.44 & 9.73 & 12.59 & 9.94 & 11.05 & 10.38 \\
\hline \multirow{4}{*}{ Potassium } & 0 & 10.03 & 9.32 & 10.07 & 14.46 & 10.52 & 11.64 & 11.01 \\
\hline & 1 & 10.86 & 11.13 & 10.81 & 14.44 & 10.21 & 12.17 & 11.60 \\
\hline & 100 & 9.00 & 8.66 & 8.04 & 9.59 & 8.43 & 8.93 & 8.78 \\
\hline & Mean & 9.96 & 9.70 & 9.64 & 12.83 & 9.72 & 10.91 & 10.46 \\
\hline \multicolumn{2}{|c|}{ Mean } & 9.75 & 9.17 & 9.69 & 12.71 & 9.83 & 10.98 & 10.42 \\
\hline $\operatorname{LSD}_{0.05}$ & \multicolumn{2}{|c|}{$\begin{array}{c}\mid=n s . \\
|x| \mid=0.468 \\
|x|||=n s .\end{array}$} & \multicolumn{3}{|c|}{$\begin{aligned} \| & =0.998 \\
\| x & \| I=0.562 \\
\| x & \| I I=0.974\end{aligned}$} & \multicolumn{3}{|c|}{$\begin{array}{c}I I I=0.688 \\
I I I x \mid=n s . \\
I I I x \| I=0.992\end{array}$} \\
\hline
\end{tabular}

ns. - not statistically significant; LSD - least significant differences

In sandy loam, treated with isopropylamine salt of glyphosate in dosage of $1 \mathrm{mg} \cdot \mathrm{kg}^{-1}$, significant changes of phosphodiesterase activity was observed on days 7,28 and 56 , while $1 \mathrm{mg} \cdot \mathrm{kg}^{-1}$ of glyphosate potassium salt caused significant changes of enzyme activity only on day 7 (19\% activation) (Table 2$)$. After application, into sandy loam, both salts of glyphosate in amounts of $100 \mathrm{mg} \cdot \mathrm{kg}^{-1}$, significant decrease of phosphodiesterase activity was showed during all experiment and this inhibition for isopropylamine and potassium salt was $10-25 \%$ and $8-34 \%$, respectively. Similarly, like in loamy sand, the level of phosphodiesterse inhibition after treatment with glyphosate salts, was in the range of negligible or acceptable values (Fig. 2).

Phoshotriesterase activity in loamy sand after addition of isopropylamine salt of glyphosate in dosage $1 \mathrm{mg} \cdot \mathrm{kg}^{-1}$ was significantly changed only on day 28 and 56 . This stimulation was 26 and $16 \%$, respectively. Significant activation of phosphotriesterase was also observed in loamy sand treated with of glyphosate potassium salt in dosage of $1 \mathrm{mg} \cdot \mathrm{kg}^{-1}$ on day 1 $(27 \%)$ and in dosage of $100 \mathrm{mg} \cdot \mathrm{kg}^{-1}$ on day $14(19 \%)$. Significant enzyme activity decrease was showed only on day 28 in soil with both glyphosate salts in dosage of $100 \mathrm{mg} \cdot \mathrm{kg}^{-1}$ (isopropylamine salt - $11 \%$; potassium salt - 13\%) and on day 112 in soil with isopropylamine salt of glyphosate in amount of $1 \mathrm{mg} \cdot \mathrm{kg}^{-1}(13 \%)$.

Application of glyphosate into sandy loam caused significant increase of phosphotriesterase activity for potassium salt in amount of $1 \mathrm{mg} \cdot \mathrm{kg}^{-1}$ on day $56(19 \%)$ and in amount of $100 \mathrm{mg} \cdot \mathrm{kg}^{-1}$ on day 14 (16\%). Significant stimulation of enzyme activity was also observed in sandy loam treated with isopropylamine salt of glyphosate in dosage of $100 \mathrm{mg} \cdot \mathrm{kg}^{-1}$ on 
A

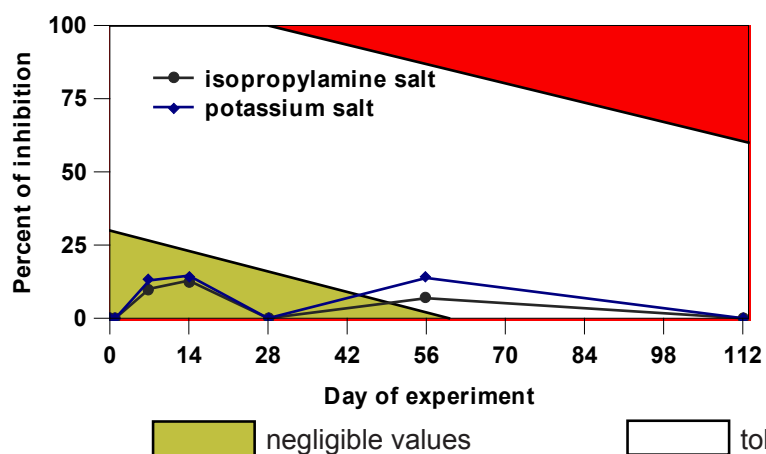

B

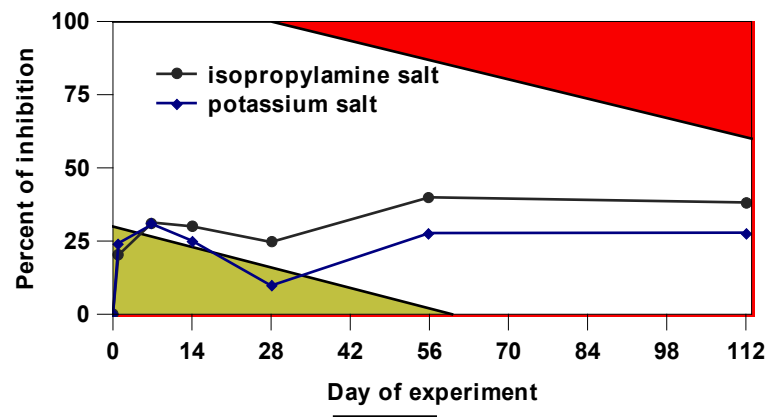

critical values

Fig. 1. The range of phosphodiesterase inhibition in loamy sand, treated with glyphosate in dosage of $1 \mathrm{mg} \cdot \mathrm{kg}^{-1}(\mathrm{~A}) \mathrm{and} 100 \mathrm{mg} \cdot \mathrm{kg}^{-1}$ (B) with reference to ecological importance of soil pollution

A

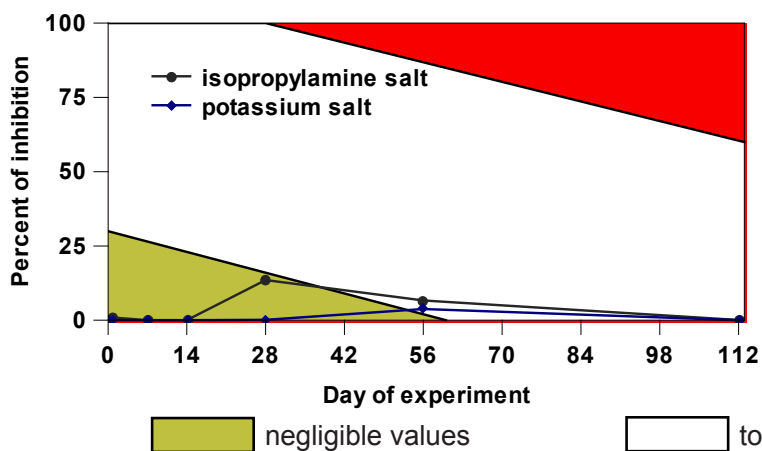

B

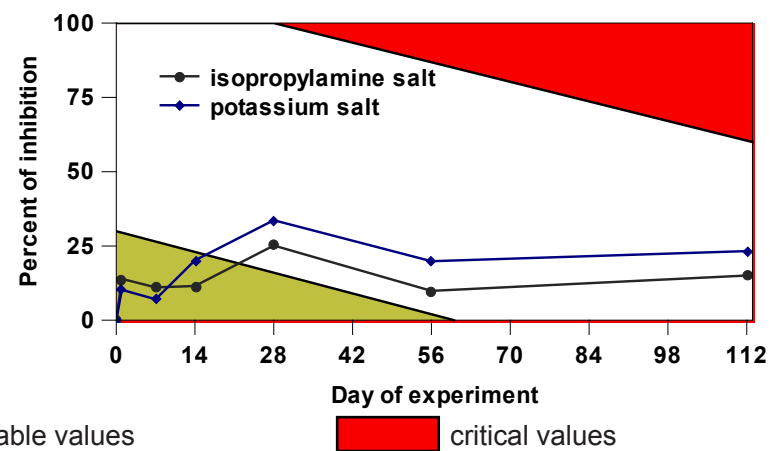

Fig. 2. The range of phosphodiesterase inhibition in sandy loam, treated with glyphosate in dosage of $1 \mathrm{mg} \cdot \mathrm{kg}^{-1}(A)$ and $100 \mathrm{mg} \cdot \mathrm{kg}^{-1}$ (B) with reference to ecological importance of soil pollution

A

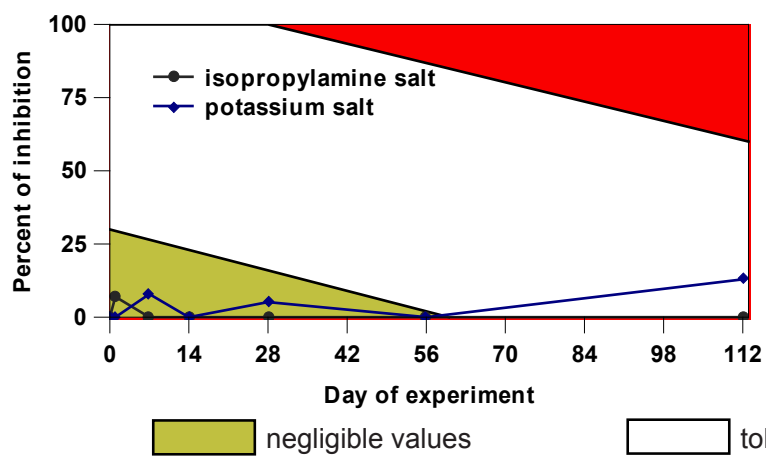

B

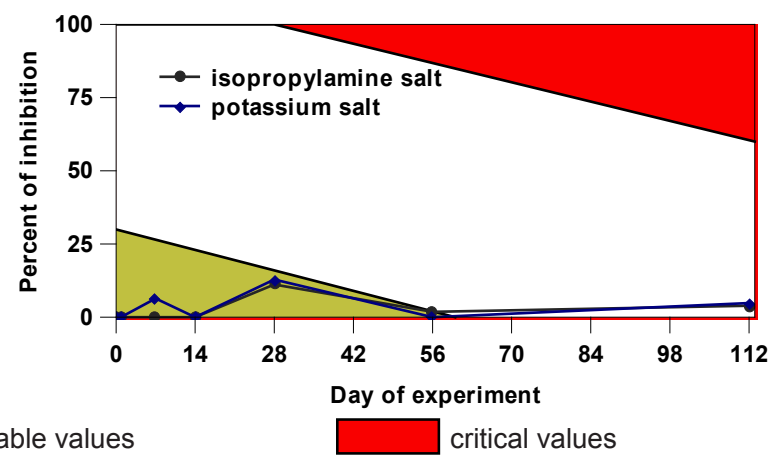

Fig. 3. The range of phosphotriesterase inhibition in loamy sand, treated with glyphosate in dosage of $1 \mathrm{mg} \cdot \mathrm{kg}^{-1}(\mathrm{~A}) \mathrm{and} 100 \mathrm{mg} \cdot \mathrm{kg}^{-1}$ (B) with reference to ecological importance of soil pollution

days $7,28,56,112(17-28 \%)$ (Table 3 ). Rarely found significant inhibition of the phosphotriesterase activity was in the range of negligible or acceptable values (Figs. 3, 4).

Application of two different glyphosate salts into loamy sand and sandy loam caused changes of phosphodiesterase and phosphotriesterase activities, that could effect on the phosphorus metabolism in soil. This is a very important problem because biogeochemical cycle of phosphorus is vulnerable to any changes caused by agriculture. In addition, changes in the content of this element in the soil can significantly impact on microbial and biochemical activity of soil [Lemanowicz and Koper 2009].

The effect of glyphosate on soil microorganisms depend on the dosage, soil texture and organic matter content [Giesy et al. 2000, Nakatani et al. 2014]. The results obtained by Tejada [2009] showed that glyphosate effect on phosphatases is higher in light soil than in clay soil. It was confirmed in our study. The most commonly observed effect of glyphosate salts was decrease in phosphodiesterase activity and increase in phosphotriesterase 
Table 3. Phosphotriesterase activity in soil treated with glyphosate salts [mg p-NP. $(\mathrm{kg} \mathrm{dm} \cdot \mathrm{h})^{-1}$ ]

\begin{tabular}{|c|c|c|c|c|c|c|c|c|}
\hline \multirow{2}{*}{$\begin{array}{l}\text { Glyphosate salt } \\
\text { (I) }\end{array}$} & \multirow{2}{*}{$\begin{array}{c}\text { Dose } \\
{\left[\mathrm{mg} \cdot \mathbf{k g}^{-1}\right] \text { (II) }}\end{array}$} & \multicolumn{7}{|c|}{ Day of experiment (III) } \\
\hline & & 1 & 7 & 14 & 28 & 56 & 112 & Mean \\
\hline \multicolumn{9}{|c|}{ Loamy sand } \\
\hline \multirow{4}{*}{ Isopropylamine } & 0 & 11.35 & 12.19 & 11.96 & 13.14 & 12.73 & 12.99 & 12.39 \\
\hline & 1 & 10.55 & 13.58 & 13.81 & 16.93 & 14.79 & 13.77 & 13.91 \\
\hline & 100 & 12.18 & 12.29 & 13.07 & 11.97 & 12.49 & 12.48 & 12.41 \\
\hline & Mean & 11.36 & 12.69 & 12.96 & 14.01 & 13.34 & 13.08 & 12.90 \\
\hline \multirow{4}{*}{ Potassium } & 0 & 11.35 & 12.19 & 11.96 & 13.14 & 12.73 & 12.99 & 12.39 \\
\hline & 1 & 14.37 & 11.22 & 13.80 & 12.71 & 14.09 & 11.31 & 12.92 \\
\hline & 100 & 11.33 & 14.41 & 14.26 & 11.68 & 12.97 & 12.36 & 12.84 \\
\hline & Mean & 12.35 & 12.61 & 13.34 & 12.51 & 13.26 & 12.22 & 12.71 \\
\hline \multicolumn{2}{|c|}{ Mean } & 11.86 & 12.65 & 13.14 & 13.26 & 13.30 & 12.65 & 12.81 \\
\hline $\mathrm{LSD}_{0.05}$ & \multicolumn{3}{|c|}{$\begin{array}{c}\mid=n s . \\
|x| \mid=n s . \\
|x|||=0.740\end{array}$} & \multicolumn{2}{|c|}{$\begin{array}{c}\|=0.629 \\
\|x\| I \|=n s . \\
\|x\| \|=1.483\end{array}$} & \multicolumn{3}{|c|}{$\begin{array}{c}I I I=1.086 \\
I I I x I=1.088 \\
I I I x \text { II }=1.340\end{array}$} \\
\hline \multicolumn{9}{|c|}{ Sandy loam } \\
\hline \multirow{4}{*}{ Isopropylamine } & 0 & 11.37 & 12.29 & 12.12 & 12,71 & 14.17 & 12.76 & 12.57 \\
\hline & 1 & 11.53 & 12.41 & 11.95 & 13.63 & 12.36 & 13.08 & 12.49 \\
\hline & 100 & 12.01 & 14.49 & 13.63 & 14.92 & 18.08 & 15.26 & 14.73 \\
\hline & Mean & 11.64 & 13.06 & 12.57 & 13.75 & 14.87 & 13.70 & 13.27 \\
\hline \multirow{4}{*}{ Potassium } & 0 & 11.37 & 12.29 & 12.12 & 12.71 & 14.17 & 12.76 & 12.57 \\
\hline & 1 & 10.71 & 12.90 & 12.56 & 11.67 & 16.91 & 13.96 & 13.12 \\
\hline & 100 & 12.12 & 13.57 & 14.17 & 13.35 & 12.36 & 13.87 & 13.24 \\
\hline & Mean & 11.40 & 12.92 & 12.95 & 12.58 & 14.48 & 13.53 & 12.98 \\
\hline \multicolumn{2}{|c|}{ Mean } & 11.52 & 12.99 & 12.76 & 13.17 & 14.68 & 13.62 & 13.12 \\
\hline $\mathrm{LSD}_{0.05}$ & \multicolumn{2}{|c|}{$\begin{aligned} I & =n s . \\
|x| \mid & =0.435 \\
|x||| & =0.436\end{aligned}$} & & \multicolumn{2}{|c|}{ 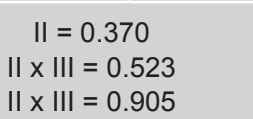 } & \multicolumn{3}{|c|}{$\begin{array}{c}I I I=0.639 \\
I I I x \mid=0.639 \\
I I I x \mid I=1.107\end{array}$} \\
\hline
\end{tabular}

ns. - not statistically significant; LSD - least significant differences

A

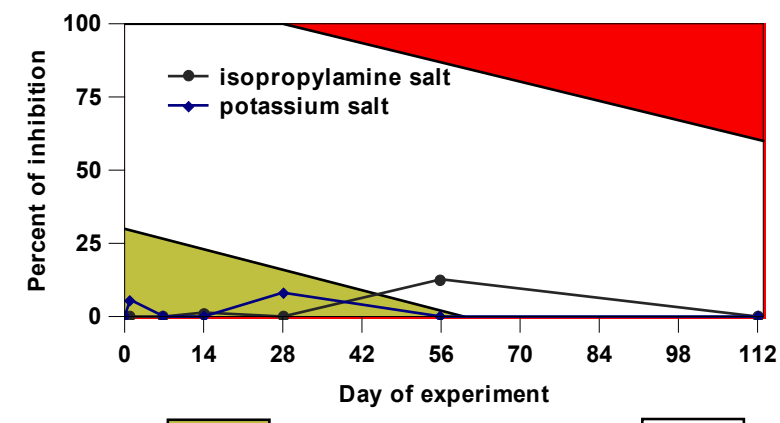

negligible values

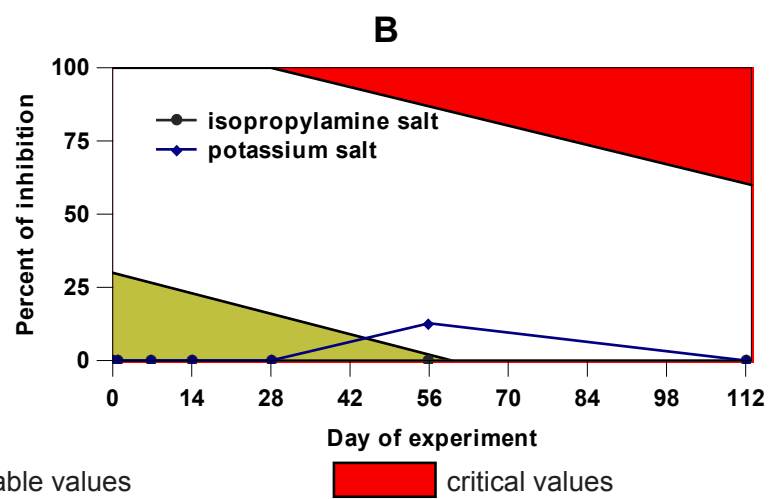

tolerable values

Fig. 4. The range of phosphotriesterase inhibition in sandy loam, treated with glyphosate in dosage of $1 \mathrm{mg} \cdot \mathrm{kg}^{-1}(\mathrm{~A})$ and $100 \mathrm{mg} \cdot \mathrm{kg}^{-1}$ (B) with reference to ecological importance of soil pollution 
activity. Floch et al. [2011] found that glyphosate and other pesticides generally had an immediate stimulating effect on phosphotriesterase, and phosphomonoesterase activities in soil. In contrast, phosphodiesterase activity was inhibited by glyphosate residues in soil. On the other hand, the glyphosate could be degraded by soil microbes and interact with soil like inorganic phosphate [Krzyśko-Łupicka and Orlik 1997]. However, our results indicate that observed phosphodiesterase and phosphotrieterase activity changes, on the graphs proposed by Domsch et al. [1983], were range of negligible or acceptable values. Nowak et al. [2003] showed, that effect of different herbicides on phosphomonoesterase activities was also in the range of negligible or acceptable values. It could indicate that glyphosate has a small effect on phosphodiesterase and phosphotriesterase activity in loamy sand and sandy loam.

\section{REFERENCES}

BROWMAN M.G., TABATABAI M.A. 1978. Phosphodiesterase activity of soils. Soil Sci. Soc. Am. J. 42: 284-290.

DOMSCH K.H., JAGNOW G., ANDERSON T.-H. 1983. An ecological concept for the assessment of side-effects of agrochemicals on soil microorganisms. Res. Rev. 86: 65-105.

EIVAZI F., TABATABAI M.A. 1977. Phosphatases in soils. Soil Biol. Biochem. 9: 167-172.

FLOCH C., CHEVREMONT A.C., JOANICO K., CAPOWIEZ Y., CRIQUET S. 2011. Indicators of pesticide contamination: Soil enzyme compared to functional diversity of bacterial communities via Biolog ${ }^{\circledR}$ Ecoplates. Eur. J. Soil Biol. 47, 4: 256-263.

FORLANI G., PAVAN M., GRAMEK M., KAFARSKI P., LIPOK J. 2008. Biochemical bases for a widespread tolerance of cyanobacteria to the phosphonate herbicide glyphosate. Plant Cell Physiol. 49: 443-456.

GIESY J.P., DOBSON S., SOLOMON K.R. 2000. Ecotoxicological risk assessment for Roundup ${ }^{\circledR}$ herbicide. Rev. Environ. Contam Toxicol. 167: 35-120.

KRZYŚKO-ŁUPICKA T., ORLIK A. 1997. The use of glyphost as the sole source of phosphorus or carbon for the selection of soil-borne fungal strains capable to degrade this herbicide. Chemosphere 34, 12: 2601-2605.

KUMAR S., MUKERJI K.G., LAL R. 1996. Molecular aspects of pesticide degradation by microorganisms. Crit. Rev. Microbiol. 22, 1: 1-26.

LANE M., LORENZ N., SAXENA J., RAMSIER C., DICK R.P. 2012. Microbial activity, community structure and potassium dynamics in rhizosphere soil of soybean plants treated with glyphosate. Pedobiologia 55: 153-159.

LEMANOWICZ J., KOPER J. 2009. Zawartość wybranych form fosforu w glebie i koniczynie łąkowej oraz aktywność fosfataz glebowych na tle zróżnicowanego nawożenia mineralnego i organicznego. Woda-Środowisko-Obszary Wiejskie 9, 4(28): 119-139.

\section{SUMMARY}

Glyphosate application has primarily resulted in inhibition of phosphodiesterase activity, and stimulation of phosphotriesterase activity in sandy loam and loamy sand. Soil type and kind of glyphosate salt affect the interaction of herbicide on phosphodiesterase and phosphotriesterase activities. The observed changes in the phosphodiesterase and phosphotriesterase activities caused by the addition of both glyphosate salts were located on environmental danger zones graphs in the range of negligible or acceptable values, which may indicate a low impact of herbicide on measured enzymes.

MALGHANI S., CHATTERJEE N., HU X., ZEJIAO L. 2009. Isolation and characterization of a profenofos degrading bacterium. J. Environ. Sci. 21: 1591-1597.

NAKATANI A.S., FERNANDES M.F., de SOUSA R.A., da SILVA A.P., dos REIS-JUNIOR F.B., MENDES I.C., HUNGRIA M. 2014. Effects of glyphosate-resistance gene on herbicide applied to the soybean crop on soil microbial biomass and enzymes. Field Crops Res. 162: 20-29.

NOWAK J., KŁÓDKA D., TELESIŃSKI A. 2003. Ocena oddziaływania trzech herbicydów : Solar 200 EC, Lontrel 300 SL, Mustang 306 SE na aktywność biologiczną gleby na podstawie aktywności fosfatazowej. Zesz. Probl. Post. Nauk Rol. 493: 233-239.

REDEL Y.D., RUBIO R., ROUANET J.L., BORIE F. 2007. Phosphorus bioavailability affected by tillage and crop rotation on a Chilean volcanic derived Ultisol. Geoderma 139: 388396.

TEJADA M. 2009. Evolution of soil biological properties after addition ofglyphosate, diflufenicanand glyphosate+diflufenican herbicides. Chemosphere 76: 365-373.

TURNER B.L., HAYGARTH P.M. 2005. Phosphatase activity in temperate pasture soils: Potential regulation of labile organic phosphorus turnover by phosphodiesterase activity. Sci. Total Environ. 344: 27-36.

WANG J.B., CHEN Z.H., CHEN L.J., ZHU A.N., WU Z.J. 2011. Surface soil phosphorus and phosphatase activities affected by tillage and crop residue input amounts. Plant Soil Environ. $57,6: 251-257$.

WIENHOLD B.J., ANDREWS A.A., KARLEN D.L. 2004. Soil quality: a review of the science and experiences in the USA. Environ. Geochem. Health 26: 89-95.

WEBSTER T.M.U., LAING L.V., FLORANCE H., SANTOS E.M. 2014. Effects of glyphosate and its formulation, Roundup, on reproduction in zebrafish (Danio rerio). Environ. Sci. Technol. 48: 1271-1279. 